\title{
PENDIDIKAN MULTIKULTURAL DI MADRASAH PEMBANGUNAN CIPUTAT TANGERANG
}

\author{
Muhamad Murtadlo \\ Puslitbang Lektur dan Naskah Keagamaan | Balitbang dan Diklat Kemenag RI \\ Jl. MH Thamrin No.06 Jakarta Pusat | Email: tadho25@gmail.com
}

\begin{abstract}
Implementation of multicultural education in madrasas is a very interesting topic to present in this paper, considering the characteristics of learners which can be said to be more homogeneous than the secular schools. In general, the multicultural education has become necessary to be applied in educational institutions with heterogeneous learners, especially in terms of their beliefs. Multicultural values taught in school will be more easily practiced in the social life among such heterogeneous students. But this is not the case with homogenous madrasas. The development of multicultural values in madrasahs will call for its own concepts and strategies. Using a qualitative research approach with in-depth interviews as the main data collection instrument, this paper tries to formulate multicultural education conducted by the Madrasah Pembangunan, Ciputat, Tangerang, by seeing how the context, concept, and its implementation in educational systems are organized. The findings include, among others, the facts that multicultural education in madrasah is nothing new because multicultural values have been taught in many subjects there. These multicultural values are developed and introduced and required by the students in Madrasah Pembangunan to deal with heterogeneous members of society such as the values of tolerance, empathy, cooperation; and four main properties of Muhammad Rasulullah (Genuine, Trustworthy, Authentic, Intelligent). Other values include confidence, quality work and competitive.
\end{abstract}

Keywords: Education, multicultural, madrasah

\begin{abstract}
Abstrak
Implementasi pendidikan multikultural di madrasah merupakan hal yang sangat menarik dipaparkan dalam tulisan ini, mengingat karakteristik peserta didiknya dapat dikatakan lebih homogen dibandingkan dengan sekolah-sekolah. Pada umumnya pendidikan multicultural menjadi kebutuhan untuk diaplikasikan pada lembaga-lembaga pendidikan dengan peserta didik yang heterogen terutama dilihat dari agama yang dianutnya. Nilai-nilai multicultural yang diajarkan di sekolah akan lebih mudah dipraktikkan dalam kehidupan social antarpeserta didik yang heterogen tersebut. Tidak demikian dengan madrasah dengan homogenitas yang dimilikinya. pengembangan nilai-nilai multicultural di madrasah memerlukan konsep dan strategi tersendiri. Tulisan ini mencoba merumuskan pendidikan pendidikan multicultural yang dilakukan oleh Madrasah Pembangunan, Ciputat, Tangerang, yaitu melihat bagaimana konteks, konsep, dan implementasinya dalam sistem pendidikan yang diselenggarakan, dengan menggunakan pendekatan penelitian kualitatif dengan wawancara mendalam sebagai instrument utama penggalian datanya. Temuannya antara lain pendidikan multikultural di lingkungan madrasah sebenarnya bukan masalah baru karena di lingkungan madrasah nilainilaimultikultural itu telah diajarkan dalam banyakmatapelajaran. Nilai-nilaimulticulturalyang dikembangkan dan diperkenalkan serta dibutuhkan peserta didik di Madrasah Pembangunan dalam menghadapi masyarakat yang heterogen seperti nilai-nilai toleransi, empati, kerjasama; dan empat sifat utama rasulullah (Siddiq, Amanah, tabligh, fathonah). Nilai-nilai lainnya adalah percaya diri, bekerja berkualitas dan berdaya saing.
\end{abstract}

Kata Kunci: Pendidikan, multikultural, madrasah 


\section{PENDAHULUAN}

Salah satu respon penting dunia pendidikan menghadapi globalisasi adalah perlunya pendidikan multicultural diajarkan kepada peserta didik di sekolah. Sebuah lembaga pendidikan dianggap siap menghadapi budaya global ketika lembaga itu mempunyai mekanisme merespon nilainilai baru yang berkembang seiring dengan globalisasi, seperti pendidikan multikultural, demokrasi, kesetaraan gender, pendidikan tanpa kekerasan. Khusus terkait dengan pendidikan multikultural di madrasah, mengingat madrasah dikenal memiliki peserta didik yang relatif homogen, bagaimana bentuk pendidikan multikultural dirumuskan?

Tidaklah mudah merumuskan seting dan bentuk pendidikan multikultural di madrasah. Kesulitan itu dirasakan, mengingat siswasiswa madrasah relatif homogen dari sisi latarbelakang keagamaan siswa. Kemungkinan perbedaan terjadi pada asal-usul orang tua yang berasal dari berbagai daerah, suku di Indonesia. Di wilayah perkotaan di mana kota menjadi tujuan migrasi penduduk dari berbagai daerah, perbedaan rasa bahasa, kesukuan, budaya dan adat istiadat menyebabkan siswa madrasah berkemungkinan mempunyai perbedaan budaya.

Berangkat dari permasalahan di atas, di sini akan dikaji ikhtiar merumuskan pendidikan multikultural yang dilakukan oleh sebuah madrasah di pinggiran Ibukota Jakarta, yaitu pada madrasah pembangunan Ciputat tangerang Selatan. Pilihan ini didasarkan pertimbangan bahwa madrasah tersebut dianggap salah satu madrasah swasta yang cukup diminati oleh masyarakat yang kebanyakan adalah urban kelas ekonomi menengah. Penelitian dirumuskan untuk menjawab bagaimana konteks, konsep dan implementasi pendidikan multikultural di madrasah.

Penelitian ini dilakukan dengan menggunakan pendekatan penelitian kualitatif. Data dikumpulkan dengan studi dokumen dan wawancara mendalam. Data dianalisis untuk mendapatkan kontruksi konsep pendidikan multikultural yang digagas oleh pengelola lembaga pendidikan madrasah.

Secara konseptual, Burbules dan Torres (2000) menyebutkan kecenderungan pendidikan dalam konteks globalisasi, di antaranya: 1) meningkatnya beberapa kebijakan popular seperti privatisasi, pilihan, dan desentralisasi sistem pendidikan yang menjadi arah pembentukan pendidikan dan pencapaian riset berbasiskan organisasi rasional dan teori managemen; 2) meningkatnya peran organisasi pendidikan baik nasional maupun internasional, termasuk organisasi guru, organisasi orang tua dan gerakan sosial; 3) meningkatnya tawaran beasiswa bagi pelajar berdasarkan kelompok, kelas, negara (terkait tema misalnya multikulturalisme, permasalahan identitas, teori kritik, feminisme, poskolonialisme, komunitas diaspora dan gerakan sosial baru. ${ }^{1}$

Hugh Lauder (2006) menyebutkan tema utama perdebatan pendidikan dewasa ini yang dia sebut sebagai era pasca kolonial (post kolonial) berpusat pada keperbedaan (diversity), inklusifitas and kewarganegaraan (citizenship). Dua kunci teoritis dan isu praktis pendidikan kontemporer, menurutnya meliputi isu demokratisasi dan perubahan ekonomi global. Dua tema ini yaitu demokratisasi dan ekonomi global berpengaruh pada dunia pendidikan ini tidak saja terjadi pada era saat ini, tetapi terjadi jauh sejak zaman kolonial. ${ }^{2}$

Pendidikan multicultural yang semula mempunyai tujuan politis menjadi alat warga Negara untuk mengontrol penguasa, pada waktu berikutnya pendidikan multicultural telah menjadi motor penggerak bagi pendidikan demokrasi, humanisme dan pluralisme yang dilakukan melalui institusi

1 Burbules dan Torres. 2000. Globalization and Education: Critical Perspective. New York: Routledge, h. 18

${ }^{2}$ Lauder, Hugh et al. 2006. Education, Globalization \& Social Change. Oxford: Oxford university Press. h.19 
pendidikan. ${ }^{3}$ Andersen dan Cusher (1994:320), pendidikan multikultural dapat diartikan sebagai pendidikan mengenai keragaman kebudayaan. James Banks (1993:3) pendidikan multikultural sebagai pendidikan untuk people of color. Artinya, pendidikan multikultural ingin mengeksplorasi perbedaan sebagai keniscayaan (anugrah tuhan atau sunatullah). Muhaemin el Ma'hady, pendidikan multikultural dapat didefinisikan sebgai pendidikan tentang keragaman kebudayaan dalam meresponi perubahan demografi dan kultural lingkungan masyarakat tertentu bahkan dunia secara keseluruhan (global).

Hilda Hernandez pendidikan multikultural sebagai prespektif yang mengakui realitas politik, sosial,dan ekonomi yang dialami oleh masing-masing individu dalam pertemuan manusia yang kompleks dan beragam secara kultur, dan merefleksikan pentingnya budaya, ras, seksualitas, agama, gender, etnisitas, status sosial, ekonomi, dan pengecualianpengecualian dalam proses pendidikan. Paulo Freire, pendidikan bukan merupakan "menara gading" yang berusaha menjauhi realitas sosial dan budaya. Pendidikan menurutnya harus mamapu menciptakan tatanan masyarakat yang terdidik dan berpendidikan, buka sebuah masyarakat yang hanya mengagungkan prestise sosial sebagai akibat kekayaan dan kemakmuran yang dialami. ${ }^{4}$

James Banks (1994), pendidikan multikultural memiliki beberapa dimensi yang saling berkaitan satu dengan yang lain, yaitu: Pertama, Content Intergration, yaitu mengintegrasikan berbagai budaya dan kerealisasi dan teori dlam mata pelajaran/disiplin ilmu. Kedua, the knowledge construction process, yaitu membawa siswa untuk memahami implikasi budaya ke dalam sebuah mata

${ }^{3}$ Ainul Yakin. 2005. Pendidikan Multikultural: Cross Cultural Understanding untuk Demokrasi dan Keadilan. Yogyakarta: Pilar Media. h.23-26

4 Freire, Paulo. 1984. Pendidikan Sebagai Praktek Pembebasan, terj. Alois A. Nugroho. Jakarta: Gramedia. h.434-459 pelajaran (disiplin). Ketiga, an equity paedagogy, yaitu menyesuaikan metode pengajaran dengan cara belajar siswa dalam rangka memfasilitasi prestasi akademik siswa yang beragam baik dari segi ras, budaya ataupun sosial. Keempat, prejudice reduction, yaitu mengidentifikasi karakteristik ras siswa dan menetukan metode pengajaran mereka.

Tilaar mengungkapkan bahwa dalam program pendidikan multikultural, fokus tidak lagi diarahkan semata-mata kepada kelompok rasial, agama dan kultural domain atau mainstream. Fokus seperti ini pernah menjadi tekanan pada pendidikan interkultural yang menekankan peningkatan pemahaman dan toleransi individu-individu yang berasal dari kelompok minoritas terhadap budaya mainstream yang dominan, yang pada akhirnya menyebabkan orang-orang dari kelompok minoritas terintegrasi ke dalam masyarakat mainstream. Pendidikan multikultural sebenarnya merupakan sikap "peduli" dan mau mengerti (difference), atau "politics of recognition" politik pengakuan terhadap orang-orang dari kelompok minoritas. ${ }^{5}$

Ickhen Safa mengangkat permasalahan tentang peran pendidikan dalam proses integrasi nasional. Proses 'national building' meliputi konsolidasi tidak hanya pada aspek material, tetapi juga dalam wilayah ideologis, penekanan tidak hanya pada usaha mobilisasi dan pengembangan sumber-sumber daya yang dimiliki Negara melainkan juga usaha pencapaian pada konsensus ideologis yang mengikat orang dalam kebersamaan nilai-nilai dan tujuan. ${ }^{6}$ Ickhen Safa mengutip salah satu

${ }^{5}$ H.A.R, Tilaar. 2002. Perubahan Sosial dan Pendidikan: Pengantar Pedagogik Transformatif untuk Indonesia. Jakarta: Grasindo. h. 189

${ }^{6}$ Dalam memaparkan tulisan ini, Ickhen Safa selain mengutip beberapa teori, dia menggunakan pendekatan komparasi antara dua penelitian kasus tentang posisi pendidikan dalam perubahan sosial. Dua penelitian yang dilakukan oleh Manning Nash (1965), yaitu tentang desa tertutup di Amatenango, Meksiko dengan desa Cantel di 
antropolog yang peduli terhadap tema 'nation building' yaitu Julian Steward yang menyatakan bahwa proses integrasi sosio kultural tidaklah hanya penyatuan sejumlah dan perbedaan aspek-aspek masyarakat, tetapi juga pada perkembangan fungsi interdependensi antar aspek itu. Dalam masyarakat kompleks, fungsi interdependensi diperankan melalui kelompok-kelompok sosial tertentu, yang disebut Steward sebagai segmen horizontal, dan melalui institusi-institusi formal Negara. Segmen-segmen horizontal itu meliputi kelompok-kelompok pekerjaan, kelas, kasta, ras, atau etnik yang melampau lokalitas dan mengikat komunitas-komunitas itu dalam subkultur-subkultur nasional baru. Institusi-institusi formal Negara itu bisa berupa keuangan, perbankan, perdagangan, sistem legal, tentara, konstitusi agama yang menciptakan masyarakat bersama dalam level nasional. $^{7}$

\section{HASIL DAN PEMBAHASAN}

\section{Profil madrasah Pembangunan, Ciputat}

Madrasah Pembangunan Ciputat, Tangerang digagas berdiri sejak tahun 1972. Madrasah ini saat pertama kali dibuka hanya melayani pendidikan tingkat dasar (setingkat Sekolah dasar). Saat ini, Madrasah Pembangunan telah melayani pendidikan dasar (Madrasah Ibtidaiyah), pendidikan menengah pertama (Madrasah Tsanawiyah)

pegunungan Guatemala. Kajian ini menyebutkan peran penting pendidikan dalam proses 'nation building', yaitu: 1) peran penting pendidikan dalam menjembatani antara komunitas tertutup dengan komunitas terbuka; 2) lembaga pendidikan yang berperan sebagai 'broker'; 3) dalam menjalankan peran pendidikan diperlukan tambahan institusi pendukung pada sekolah; 4) pentingnya dukungan pemerintah. Lihat Safa, Helen Ickhen, 1971, "Education, Modernization, and the The Proses of National Integration, " dalam Anthropological Perspectives on Education (edit by Murray Wax et al.). New York: Basic Books, Inc. h. 224-228

${ }^{7}$ Safa,HelenIckhen.1971."Education, Modernization, and the The Proses of National Integration, "dalam Anthropological Perspectives on Education (edit by Murray Wax et al.). New York: Basic Books, Inc, h. 213 dan pendidikan menengah atas (Madrasah Aliyah). Kegiatan Belajar Mengajar (KBM) di madrasah Pembangunan dimulai sejak tanggal 7 Januari 1974, dan tanggal itulah yang kemudian ditetapkan sebagai "Hari Kelahiran" MP IAIN Jakarta. ${ }^{8}$ Saat pertama kali Madrasah Pembangunan (MP) membuka kelas, siswa yang masuk hanya 7 anak. Tahun kedua juga hanya delapan anak. Baru tahun ketiga anak yang mendaftar meningkat yaitu 43 anak. Sejak itu tahun demi tahun jumlah siswa terus berkembang. ${ }^{9}$

Madrasah Pembangunan adalah sekolah terpadu, yaitu sekolah dengan berbagai tingkatan dari sekolah dasar hingga sekolah menengah atas yang berada dalam satu lokasi. Pada tahun 2008, pada Madrasah Ibitidaiyah memiliki kelas I sampai dengan kelas VI, masing-masing jenjang kelas mempunyai 8 atau 9 rombongan belajar, total rombongan belajar 50 kelas. Untuk Madrasah Tsanawiyah meliputi tiga jenjang kelas VII sampai dengan kelas IX, masing-masing jenjang sebanyak 7 kelas, total kelas sebanyak 21 kelas. Untuk tingkat Madrasah Aliyah meliputi kelas X sampai dengan kelas XII, masing-masing kelas sebanyak 2 kelas, total kelas sebanyak 6 kelas. Jumlah siswa Madrasah Pembangunan secara keseluruhan berjumlah kurang lebih 2. 500 siswa. $^{10}$

Saat penelitian ini dilakukan, Madrasah Pembangunan berhasil menempatkan diri menjadi lembaga pendidikan yang diminati oleh masyarakat kelas ekonomi menengah di Kota Metropolitan Jakarta. Kenapa saya

${ }^{8}$ Madrasah ini tidak saja melayani pendidikan formal tingkat dasar melalui Madrasah Ibtidaiyah (setingkat SD), tetapi juga Madrasah Tsanawiyah (setingkat SMP), tetapi juga melayani pendidikan tingkat menengah yaitu melalui Madrasah Aliyah (Setingkat SMA).

${ }^{9}$ Saat penelitian ini dilakukan (2009) jumlah siswa Madrasah Pembangunan telah mencapai 1771 siswa. Angka yang fantastik untuk ukuran satuan pendidikan di Ibukota.

${ }^{10}$ Data tahun 2008, Jumlah total siswa pada ketiga tingkatan pendidikan tersebut dapat disebutkan untuk Madrasah Ibtidaiyah sebanyak 1. 721 siswa, untuk Madrasah Tsanawiyah terdapat 700 siswa, dan untuk tingkat Madrasah Aliyah sebanyak 180 siswa. 
menyebut konsumen madrasah ini adalah masyarakat kelas sosial ekonomi menengah ke atas, hal ini saya simpulkan dari kemampuan orang tua membayar biaya pendidikan pada madrasah tersebut. Untuk tahun 2009, uang pangkal yang harus dibayarkan orang tua siswa kepada lembaga pendidikan itu sebanyak sepuluh juta rupiah. Jumlah yang cukup besar untuk ukuran biaya pendidikan jenjang sekolah dasar.

Untuk menggambarkan konsumen dari Madrasah Pembangunan, berikut penulis paparkan datadeskripsi latar belakang keluarga siswa MP. Berdasarkan data penerimaan siswa baru MP pada tahun 2010, menunjukkan bahwa semua ruang kelas I (Satu) sebanyak 8 ruang terisi penuh. Mengikuti prasyarat Sekolah Standar Nasional (SSN) yang mensyaratkan jumlah anggota tiap rombel yang ideal adalah 28 anak, maka MP hanya menampung delapan rombel dengan jumlah siswa baru sebanyak 224 anak. Kedelapan rombel/kelas dimaksud, dari tahun 2000 hingga tahun 2010 berhasil dipenuhi oleh MP, bahkan tidak jarang Madrasah Pembangunan menolak sebagian pendaftar yang lain.

Latar belakang ekonomi. Dilihat dari kelas ekonomi keluarga siswa Madrasah Pembangunan, diketahui bahwa sebagian besar (mayoritas) orang tua siswa MP berasal dari keluarga berkategori menengah. Hal ini dapat ditunjukkan dengan indikator kemampuan orang tua dalam memenuhi prasyarat untuk menjadi siswa MP yang harus membayar uang gedung sebesar Rp. 13 juta. Dari data di lembaga pendidikan tersebut (lihat tabel), diketahui bahwa orang tua yang berpendapatan kurang dari satu juta ternyata tidak ada, dari orang tua dengan pendapatan antara 1 juta s.d 2.5 juta terdapat $15.9 \%$; dari orang tua berpendapatan di atas 2.5 juta sebanyak $84.1 \%$. Diduga, dibalik data tersebut masih banyak orang tua yang berpendapatan di atas 5 juta atau bahkan 10 juta, mengingat dari fasilitas antar jemput anak yang disediakan orang tua banyak menggunakan mobil pribadi dengan tahun keluaran di atas tahun 2000. Dari pendataan ini tidak terpetakan variasi di antara orang tua yang berpendapatan di atas 2.5 juta, karena budaya masyarakat kita belum terbiasa menyebutkan pendapatan riil mereka setiap bulan.

Pendidikan orang tua. Dilihat dari latar belakang pendidikan orang tua siswa dapat disebutkan mayoritas orang tua siswa MP berpendidikan sarjana baik itu Strata satu (S1), Strata Dua (S2) maupun Strata Tiga (S3). Data menunjukkan orang tua berpendidikan S1 ke atas sebanyak $78.7 \%$; orang tua berlatar belakang pendidikan Diploma sebanyak 11.5\%; sedangkan orang tua berpendidikan SLTA ke bawah sebanyak 9.8\%. Ini menunjukkan bahwa orang tua peminat terhadap MP yang sebagaian besar berpendidikan S1 ke atas menunjukkan bahwa pilihan tersebut telah didukung oleh tingkat rasionalitas dan pendidikan yang memadai.

Pekerjaan Orang Tua. Dari jenis pekerjaan yang menjadi profesi orang tua, dapat ditunjukkan bahwa sebagian besar adalah pegawaiswasta.Selengkapnyadapatdisebutkan orang tua berprofesi sebagai pegawai swasta sebanyak 49.3\%; pegawai negara (PNS dan TNIPOLRI) sebanyak 18.9\%; Guru/dosen sebanyak 7.5\%; pedagang/wirausaha sebanyak $17.6 \%$ dan lain-lain sebanyak $6.7 \%$.

Menghadapi globalisasi pendidikan, madrasah pembangunan mencoba merumuskan permasalahan yang dihadapi oleh Madrasah ke depan. Dalam dokumen kurikulum Madrasah Pembangunan disebutkan beberapa perkembangan dan tantangan masa depan. Perkembangan dan tantangan itu antara lain menyangkut: 1) Perkembangan ilmu pengetahuan dan teknologi; 2) Globalisasi yang memungkinkan sangat cepatnya arus perubahan dan mobilitas antar dan lintas sektor serta tempat; 3) Era informasi; 4) Pengaruh globalisasi terhadap perubahan perilaku dan moral manusia; 5) Berubahnya kesadaran masyarakat dan orang tua terhadap 
pendidikan. ${ }^{11}$ Dokumen ini menunjukkan bahwa pengelola Madrasah Pembangunan telah menyadari beberapa permasalahan krusial lembaga pendidikan saat ini, khususnya terkait dengan globalisasi pendidikan.

Madrasah Pembangunan termasuk lembaga pendidikan yang melihat secara optimis tantangan pendidikan dalam konteks globalisasi pendidikan. Menon menyebutkan meski globalisasi telah melahirkan berbagai hal negatif seperti komersialisasi pendidikan, ternyata ada beberapa keuntungan globalisasi bagi dunia pendidikan seperti munculnya kesadaran ketertinggalan praktik dunia pendidikan sejauh ini dan tuntutan pendekatan pendidikan yang lebih efektif dan memacu kompetisi. ${ }^{12}$

Denis Lawton dan Robert Cowen telah membuat periodesasi sejarah kecenderungan pergerakan dunia pendidikan, dengan referensi dunia Barat. Menurutnya, secara singkat bisa dipaparkan bahwa kecenderungan pendidikan pada periode awal masih didominasi pandangan agama dan pandangan dunia (sampai abad 19). Periode berikutnya berkembang wacana baru dalam pendidikan bersamaan dengan munculnya fenomena nation state, pendidikan yang mengembangkan nilai-nilai citizenship dan nasionalisme. Periode berikutnya berkembang wacana pendidikan yang berorientasi ekonomi. Dalam orientasi pendidikan ini sesuai dengan prinsip ekonomi maka dikembangkanlah nilai-nilai efisiensi dan efektifitas. Periode berikutnya, menyadari dampak dari tehnologi informasi yang telah melahirkan fenomena globalisasi, maka pendidikan dituntut untuk mengembangkan nilai-nilai baru yang lebih humanis seperti munculnya kesadaran baru untuk mengembangkan moral bersama seperti

\footnotetext{
${ }^{11}$ Kurikulum MI Pembangunan UIN Jakarta, 2007

${ }^{12}$ Menon, M. Govin Kumar. 2007. “Globalization and Education: An Overview" in Sorondo (ed.) Globalization and Education. Berlin: de Gruyter. h. 1
}

'inklusivitas', 'pluralisme' dan 'kesamaan kesempatan. ${ }^{13}$

Sesuai dengan konteks tulisan ini, maka tulisan ini akan kita fokuskan pada pendidikan multikutural yang telah digagas oleh madrasah Pembangunan ciputat, Tangerang Selatan.

\section{Gagasan Pendidikan Multikultural}

Untuk menggali pengembangan pendidikan multikultural di Madrasah Pembangunan, saya mewawancarai pelaku utama pengembangan pendidikan di madrasah itu, yaitu seorang guru, bernama YS (42 tahun). Dia adalah seorang guru saat itu sekaligus wakil kepala madrasah. Peran YS ini memegang peran yang penting seperti distribusi peran antar sesama pengelola harian madrasah, seorang yang mengajar mata pelajaran tertentu, juga YS ini adalah guru yang paling mengerti tentang kebijakan pengembangan wawasan multikultural di madrasah Pembangunan.

Untuk mengawal pengembangan pendidikan multikultural ini, Pak YS dipercaya untuk memimpin tim yang diberi nama Tim habitual curiculum sebagai usaha untuk mencari metode yang paling pas dalam pengembangan nilai-nilai multikultural pada berbagai mata pelajaran. Saat itu, pengembangan pendidikan multikultural, menurut YS lancar dan tidak ada penolakan sama sekali dari semua unsur atau bagian dari keluarga Madrasah Pembangunan.

Menurut YS, pendidikan multikultural diarahkan untuk memahami dan menghargai perbedaan.

“... pendidikan multikulturalisme di MP lebih ditujukan untuk memahamkan perlunya menghargai perbedaan. Perbedaan dalam konteks MP tidak fokus dengan latar belakang agama, mengingat siswa MP semuanya beragama Islam. Pemahaman multikulturalisme lebih diarahkan pada pembentukan sikap menghargai perbedaan

${ }^{13}$ Lawton, Denis dan Robert Cowen. 2001, "Values, Culture and Education: an Overview" dalam buku Values, Culture and Education. USA: Stylus Publishing Inc. h. 24 
berdasarkan kesukuan dan adat-istiadat...." (YS, 2010).

Sejak kapan pendidikan multikultural digagas di madrasah ini? Menurut Ys, Pendidikan multikultural mulai digagas di Madrasah Pembangunan sejak tahun 2005, yaitu sejak adanya adanya tawaran dari Pusat Kajian Pembangunan Masyarakat (PKPM) Universitas Katholik Atmaja Jakarta. Pusat kajian Universitas Atma Jaya Jakarta mencoba bekerjasama dengan 8 (delapan) sekolah di Jakarta merumuskan pendidikan multikultural di sekolah. Madrasah Pembangunan ditunjuk mewakili lembaga pendidikan berlatar belakang komunitas Muslim. ${ }^{14}$

Tawaran dari Universitas Atma Jaya Jakarta itu direspon secara positif oleh Madrasah Pembangunan. Sebagai bentuk tanggapan positif tersebut, Pimpinan Madrasah PembangunanmenunjukPakYSuntukmewakili Madrasah pembangunan dalam setiap kegiatan yang diselenggarakan oleh PKPM Atma Jaya Jakarta. Dari beberapa kali pertemuan dan usaha percobaan pengembangan pendidikan multikultural di masing-masing sekolah/ madrasah maka dihasilkan buku-buku modul tentang pengembangan model pendidikan multikultural untuk anak usia sekolah yang terdiri dari dua buku: panduan untuk guru dan panduan untuk anak. Buku ini diterbitkan oleh PKPM Unika Atma Jaya Jakarta bekerjasama dengan The Embassy of the United States of America (terbit November, 2006). ${ }^{15}$

${ }^{14}$ Kedelapan sekolah itu adalah SDN Sunter Agung 03 Pagi (Jakarta Utara), SDN Lebak Bulus 06 (Jakarta Selatan), SDN Kelapadua Wetan 01 (Jakarta Timur), SD Andreas (Sekolah Katolik, Jakarta Barat), SDN Kenari 07 (Jakarta Pusat), SD PSKD (Sekolah Protestan, Depok), MI Pembangunan Jakarta (Sekolah Islam, Ciputat), dan SD Ananda (Sekolah Budha, Bekasi)

${ }^{15}$ Dalam buku panduan itu dirumuskan 7 (tujuh) nilai multikulturalisme yang perlu dikembangkan, yaitu: toleransi, solidaritas, empati, musyawarah, egaliter, pengungkapan diri, keadilan. Di samping nilai-nilai positif tersebut, buku ini juga menyebutkan 7 (tujuh) nilai-nilai yang perlu dihindari dalam konteks pendidikan multikultural, yaitu: apatis, stigma, prasangka, stereotip, diskriminasi, otoriter dan egoism.
Dalam pengalaman MP berikutnya, pendidikan multikultural sebagaimana diakui oleh YS, dianggap penting dalam konteks pengembangan budi pekerti dalam konteks kenegaraan. Ketika mata pelajaran Pendidikan Kewargaan (PKn) dirasakan kurang mengembangkan budi pekerti, maka pendidikan multikultural dirasakan perlu diajarkan kepada siswa. Berikutnya MP mencoba mengembangkan pendidikan multikultural melalui pelajaran Pendidikan Kewarganeragaraan (PKn).

“... pendidikan multikultural menjadi penting ketika mata pelajaran Pendidikan Kewarganegaraan (PKn) mulai kehilangan aspek pengembangan budi pekerti siswa. PKn cenderung tidak berbeda dengan pelajaran Ilmu Pengetahuan Sosial (IPS). Pelajaran ini hanya menekankan aspek kognitif, seberapa jauh siswa mengetahui deskripsi tentang Negara. Pendidikan multikulturalisme hadir mengisi ruang kosong itu..."(Guru YS, 2010)

Implementasi pendidikan multikultural di Madrasah Pembangunan sendiri diwujudkan pada tahun 2006 melalui beberapa langkah kegiatan pendahuluan seperti penyusunan Rencana Pengembangan Pembelajaran (RPP) yang bernuansa pendidikan multikultural dan pengembangan nilai-nilai multikultural di semua mata pelajaran yang mungkin dan bisa dimasuki penanaman nilai-nilai multikultural, seperti mata pelajaran IPS, akhlak (baca: etika).

Dalam Rencana Pengembangan Pembelajaran (RPP) bernuansa pendidikan multikultural dikembangkan standar kompetensi yang ingin dicapai adalah Kemampuan siswa memahami fakta, konsep dan generalisasi tentang sistem sosial dan budaya dan menerapkannya untuk menghargai keanekaragaman sosial budaya dalam masyarakat multikultur.

Selain melalui pembelajaran kurikuler, pendidikan multikultural juga disemaikan dalam kegiatan ekstra kurikuler seperti kegiatan untuk mengalami dunia sehari-hari yang berbeda, yaitu dengan adanya beberapa 
kegiatan yang dikemas dalam jambore ekstra kurikuler.

Sfy, Pengurus Yayasan Madrasah Pembangunan, menjelaskan bahwa penanaman sikap multikultural juga dilakukan di luar kelas:

Untuk menanamkan sikap seperti itu, Madrasah Pembangunan mencoba membuat beberapa kegiatan yang mendukung, seperti jambore kegiatan ekstra kurikuler dengan menginap di rumah penduduk sebuah tempat yang ditunjuk menjadi lokasi jambore. Dengan tinggal di rumah warga, para siswa dituntut untuk bisa menerima kenyataan berbeda bila dibandingkan tinggal di rumah orang tuanya. Beberapa kegiatan lain yang mendukung tumbuhnya pemahaman multikultural yang dilakukan MP adalah seperti mengikuti lomba antar satuan pendidikan yang diadakan oleh sekolah non Islam, MP mengundang sekolah lain, termasuk sekolah Kristen, Katholik untuk mengadakan lomba dengan mengambil lokasi di MP. Mengundang guru-guru non muslim untuk mengisi kegiatan atau mata pelajaran tertentu di Madrasah." (sfy, 2011)

\section{Operasionalisasi Pendidikan Multikultural}

Nilai-nilai pendidikan multikultural di madrasah pembangunan dibangun diawali dari penerjemahan visi dan misi madrasah ini yang terkait dengan pendidikan multikultural yang diajarkan melalui mata pelajaran tertentu, dalam hal ini mata pelajaran Pendidikan Kewarganegaraan (PKn). Implementasi pendidikan multikultural di MP ini dapat dilihat dari bentuk silabus dan rencana pengembangan belajar (RPP) mata pelajaran tersebut.

Silabus. Silabus Pendidikan multikultural yang paling dekat secara materi pembelajaran adalah pendidikan kewarganegaraan (PKn). Karena itu pendidikan Kewargaan disusun berbasiskan pendidikan multikultural dengan standar kompetensi sebagai berikut: a) Menerapkan hidup rukun dalam perbedaan; b) Memahami dan menerapkan hidup rukun di rumah dan di sekolah; c) Memahami kewajiban sebagai warga dalam keluarga dan sekolah; d) Memahami hidup tertib dan gotong royong; e) Menampilkan sikap cinta lingkungan dan demokratis; f) Menampilkan perilaku jujur, disiplin, senang bekerja dan anti korupsi dalam kehidupan sehari-hari, sesuai dengan nilai-nilai pancasila; g) Memahami sistem pemerintahan, baik pada tingkat daerah maupun pusat; h) Memahami makna keutuhan negara kesatuan Republik Indonesia, dengan kepatuhan terhadap undang-undang, peraturan, kebiasaan, adat istiadat, kebiasaan, dan menghargai keputusan bersama; i) Memahami dan menghargai makna nilai-nilai kejuangan bangsa; j) Memahami hubungan Indonesia dengan negara tetangga dan politik luar negeri.

Rencana Pengembangan Pembelajaran (RPP). Dari beberapa Rencana Pengembangan Pembelajaran (RPP) yang berhasil saya amati, pendidikan multikulturalisme yang muncul dalam mata pelajaran Pendidikan Kewarganegaraan (PKn) di madrasah sudah mengenalkan perbedaan dan keragamaan suku-suku yang ada di Indonesia, mengenalkan perlunya hidup gotong royong, mengenalkan prilaku-prilaku baik di tengah perbedaan, mengenal sistem pemerintahan yang berlaku, dan mengenalkan nilai-nilai kejuangan. Salah satu RPP terkait dengan pengenalan perbedaan dan keragamaan suku-suku dan budaya di Indonesia dapat dilihat dalam lampiran.

Dari praktek pembelejaran pendidikan multikultural di Madrasah Pembangunan, saya memperoleh gambaran bahwa pendidikan multikultural itu sudah dikemas dalam konsep pengembangan budi pekerti. MP menyusun nilai-nilai utama budi pekerti, yang oleh YS disebut core values. Dari salah satu contoh Rencana Pengembangan Pembelajaran (RPP) mata pelajaran Pendidikan Kewarganegaraan (PKn) yang menekankan pengenalan terhadap suku-suku yang ada di Indonesia. Dalam RPP ini ingin dikembangkan nilai- 
nilai multikultural seperti keberanian pengungkapan identitas diri/identitas kesukuan, tidak mudah berprasangka jelek (prejudice), mengembangkan sikap saling menghargai dan tidak membeda-bedakan. Mata pelajaran ini juga ingin mengajarkan perlu menghindari sikap mudah berprasangka dan sikap diskriminasi/membedakan-bedakan.

Lebih lanjut, pengembangan pendidikan multikultural di Madrasah Pembangunan pada tahun 2010 dirumuskan dalam bentuk penyusunan core values (nilai inti). core values disusun berjumlah dua belas, sesuai dengan jumlah bulan dalam setahun. Tiap bulan dengan multi pendekatan diajarkan satu core values sebagai usaha penekanan terhadap masingmasing nilai pendidikan multicultural. Tehnik yang dilakukan adalah dengan cara core value itu dimasukkan pada semua mata pelajaran yang mungkin menjadi media menajaman nilai-nilai dimaksud. Adapun kedua belas core values itu meliputi: menjadi pendengar yang baik, percaya diri, kesetaraan, kasih sayang, empati, keadilan, nasionalisme, kerjasama, toleransi, prasangka baik, saling percaya dan tanggung jawab.

Tabel 1.

Core Values Pengembangan Budi Pekerti dalam Satu Tahun Di Madrasah Pembangunan

\begin{tabular}{|c|c|}
\hline \multicolumn{1}{|c|}{ Bulan } & $\begin{array}{c}\text { Fokus Core Values } \\
\text { Dalam Pembelajaran } \\
\text { Bulan ke 1 }\end{array}$ \\
\hline Bulan ke 2 & Pendengar Yang Baik \\
\hline Bulan ke 3 & Kesetaraan, \\
\hline Bulan ke 4 & Kasih Sayang \\
\hline Bulan ke 5 & Empati, \\
\hline Bulan ke 6 & Keadilan \\
\hline Bulan ke 7 & Nasionalisme \\
\hline Bulan ke 8 & Kerjasama \\
\hline Bulan ke 9 & Toleransi \\
\hline Bulan ke 10 & Prasangka Baik \\
\hline Bulan ke 11 & Saling Percaya \\
\hline Bulan ke 12 & Tanggung Jawab \\
\hline
\end{tabular}

Nilai-nilai itu diterjemahkan dan dirumuskan muatan nilai yang diinginkan dan indikator-indikator yang disusun sebagai ukuran keberhasilan penanaman nilai multikultural. Nilai-nilai yang menjadi pokok materi pendidikan multikultural dipilih dalam 12 (dua belas) nilai utama. Masing-masing nilai menjadi konsentrasi pengembangan untuk setiap bulannya. Penerjemahan lebih lengkap nilai-nilai multikultural tersebut disusun dan dirancang oleh Pak Ys serta pernah dipresentasikan dan dimatangkan dalam lokakarya dan seminar Multikultural yang diselengggarakn PKPM Unika Atmajaya, di Hotel Grand Melia Jakarta dan di Hotel Mirah Bogor yang diikuti yang bersangkutan.

Di mulai tahun ajaran baru, maka fokus pengembangan nilai pada bulan pertama dimulai dengan core values menjadi “pendengar yang baik.' Selengkapnya rumusan konsep dan indikatornya yang menjadi muatan pengembangan nilai setiap bulannya dioperasionalkan sebagai berikut:

\section{Pendengar Yang Baik (Bulan ke-1)}

Pada bulan pertama ajaran baru, kurang lebih bulan Juli dikembangkan nilai menjadi "pendengar yang baik". Tujuan nilai ini adalah menjadikan peserta didik memiliki kesadaran bahwa di luar dirinya ada orang-orang di sekitar yang perlu didengar pendapatnya seperti teman, guru, pimpinan madrasah. Kemauan menjadi pendengar ini penting agar seseorang tidak merasa paling benar, karena ada kebenaran lain yang perlu dicermati dari orang-orang sekitar dalam memutuskan sesuatu masalah bersama.

Indikator keberhasilan pendidikan ini diukur dengan munculnya sikap pada diri peserta didik seperti: 1) Kemauaan siswa menyimak pendapat orang lain; 2) siswa tidak egois memaksakan pendapatnya pada orang lain

\section{Percaya Diri (Bulan ke-2)}

Pada bulan kedua, ditanamkan nilai "percaya diri." Tujuan nilai ini adalah Peserta didik memiliki kesadaran untuk percaya atas 
kemampuan dirinya bisa menyumbangkan sesuatu/berpartisipasi di lingkungannya, keyakinan bahwa seseorang dibekali Tuhan dengan suatu kelebihan, sehingga bangga atas usaha kerasnya/optimis untuk mencapai tujuan, tidak ikut-ikutan melakukan sesuatu yang tidak dipahami (punya prinsip sendiri).

Indikator keberhasilan pendidikan ini diukur dengan munculnya sikap pada diri peserta didik seperti:1) Yakin atas kemampuan diri sendiri; 2) Tidak bergantung kepada bantuan orang lain.

\section{Kesetaraan (Bulan ke-3)}

Tujuan nilai ini adalah peserta didik memiliki pandangan bahwa manusia dalam suatu keadaan yang sama, manusia ditakdirkan sama sederajat dan memiliki peran masing-masing untuk saling melengkapi, memperlakukan orang lain sederajat tidak memandang perbedaan suku, sosial ekonomi, golongan, keyakinan dan sebagainya

Indikator keberhasilan pendidikan ini diukur dengan munculnya sikap pada diri peserta didik seperti: 1) Tidak membedabedakan antar sesama; 2) Mau bekerja sama tanpa membedakan jenis kelamin; 3) Tidak membedakan strata sosial; 4) Mengakui dan memperlakukan manusia sesuai dengan harkat dan martabatnya sebagai makhluk Tuhan Yang Maha Esa; 5) Mengakui persamaan derajat, pesamaan hak dan kewajiban asasi setiap manusia tanpa membedakan suku, keturunan, agama, kepercayaan, jenis kelamin, kedudukan sosial, warna kulit, dan sebagainya; 6) Sebagai warga negara dan warga masyarakat, setiap manusia Indonesia mempunyai kedudukan, hak da kewajiban yang sama.

\section{Kasih Sayang (Bulan ke-4)}

Tujuan nilai ini adalah peserta didik mempunyai perasaan cinta/sayang kepada sesama makhluk Tuhan dan melakukan kegiatan/tindakan kepada orang lain atas dasar cinta untuk kebaikan bersama.
Indikator keberhasilan pendidikan ini diukur dengan munculnya sikap pada diri peserta didik seperti: 1) Suka menolong, mengayomi, dan mengasihi antar sesama; 2) Menghindari rasa benci terhadap orang lain; 3 ) Menyanyangi orang lain seperti menyayangi diri sendiri; 4) Mengembangkap sikap saling mencintai sesama manusia; 5) Mengembangkap sikap tidak semena-mena terhadap orang lain; 6) Menjunjung tinggi nilai-nilai kemanusiaan; 7) Gemar melakukan kegiatan kemanusiaan.

\section{Empati (Bulan ke-5)}

Tujuan nilai ini adalah peserta didik mempunyai kesadaran seseorang terhadap perasaan, kebutuhan, dan kepentingan orang lain. Dengan adanya kesadaran tersebut seseorangmencobamenyeimbangkan perasaan dan pemikiran rasionalnya. Seseorang bisa berempati jika mampu memahami perasaan dan pemikiran orang lain.

Indikator keberhasilan pendidikan ini diukur dengan munculnya sikap pada diri peserta didik seperti: 1) Ikut merasakan penderitaan yang dialami orang lain; 2) Mengunjungi teman/saudara yang mendapat musibah.

\section{Keadilan (Bulan ke-6)}

Tujuan nilai ini adalah peserta didik mempunyai kesadaran untuk memperlakukan orang lain tidak berat sebelah/tidak memihak dan tidak membedakan keberpihakan kepada sesama karena perbedaan warna kulit, golongan, suku, agama, ekonomi, jenis kelamin, dan lain sebagainya.

Indikator keberhasilan pendidikan ini diukur dengan munculnya sikap pada diri peserta didik seperti: 1) Membangi tugas sesuai kemampuan masing-masing; 2) Mengambil keputusan dengan tidak berat sebelah; 3) Memberikan sesuatu sesui dengan hak-haknya; 4) Mengembangkan sikap adil terhadap sesama; 5) Menjaga keseimbangan antara hak dan kewajiban. 


\section{Nasionalisme (Bulan ke-7)}

Tujuan nilai ini adalah peserta didik mempunyai kesadaran keanggotaan dalam suatu bangsa yang secara potensial atau aktual bersama-sama mencapai, mempertahankan, dan mengabdikan identitas, integritas, kemakmuran, dan kekuatan bangsa itu; semangat kebangsaan untuk bekerja sama dengan bangsa lain dalam kerangka memajukan bangsanya.

Indikator keberhasilan pendidikan ini diukur dengan munculnya sikap pada diri peserta didik seperti: 1) Mencintai tanah air dan bangsa, bangga berbangsa dan bernegara Indonesia; 2) Membiasakan melakukan pekerjaan secara ikhlas untuk kemajuan bangsa dan negara; 3) Sebagai bangsa Indonesia harus merasa dirinya sebagaibagian dariseluruhumat manusia; 4) Mengembangkan sikap hormat menghormati dan bekerja sama dengan bangsa lain; 5) Mampu menempatkan persatuan, kesatuan serta kepentingan dan keselamatan bangsa dan negara sebagai kepentingan bersama di atas kepentingan pribadi atau golongan; 6) Memelihara ketertiban dunia yang berdasarkan kemerdekaan, perdamaian abadi dan keadilan sosial; 7) Mengembangkan rasa kebanggaan berkebangsaan dan bertanah air Indonesia; 8) Mengembangkan persatuan Indonesia atas dasar Bhinneka Tunggal Ika.

\section{Kerjasama (Bulan ke-8)}

Tujuan nilai ini adalah peserta didik mempunyai kesadaran dan kemauan menjalin kerja sama dengan orang lain tanpa memandang perbedaan ras/warna kulit, golongan, suku, agama, ekonomi, jenis kelamin untuk mencapai kebaikan bersama.

Indikator keberhasilan pendidikan ini diukur dengan munculnya sikap pada diri peserta didik seperti: 1) Menyelesaikan tugas yang menjadi tanggung jawab bersama; 2) Tidak mementingkan diri sendiri; 3) Mengembangkan perbuatan yang luhur, yang mencerminkan sikap dan suasana kekeluargaan dan kegotongroyongan.

\section{Toleransi (Bulan ke-9)}

Tujuan nilai ini adalah peserta didik memiliki kesadaran untuk mau menenggang (menghargai, membiarkan, membolehkan) pendirian, pendapat, pandangan, keyakinan, kebiasaan, kelakuan) yang berbeda atau yang bertentangan. Toleran juga bisa berarti tenggang rasa atau dapat menghargai perasaan orang lain.

Indikator keberhasilan pendidikan ini diukur dengan munculnya sikap pada diri pesertadidikseperti:1)Menghormatioranglain yang berbeda keyakinan, kebiasaan, kelakuan, budaya dan sebagainya; 2) Tidak memaksakan kehendak kepada orang lain; 3) Memberikan kebebasan kepada umat lain untuk melakukan ibadah sesuai agamanya; 4) Mengembangkan sikap saling tenggang rasa dan tepa selira; 5) Mengembangkan sikap hormat menghormati dan bekerja sama dengan semua orang (antara pemeluk agama, antar suku, antar golongan dan sebagainya); 6) Membina kerukunan hidup di antara sesama umat beragama dan kepercayaan terhadap Tuhan Yang Maha Esa; 7) Mengembangkan sikap menghormati kebebasan menjalankan ibadah sesuai dengan agama dan kepercayaannya masing-masing; 8) Tidak memaksakan suatu agama kepada orang lain; 9) Tidak memaksakan kehendak kepada orang lain; 10) Menghormati hak orang lain.

\section{Prasangka Baik (Bulan ke-10)}

Tujuan nilai ini adalah peserta didik mempunyai pendapat (anggapan) baik mengenai sesuatu sebelum mengetahui (menyaksikan, menyelidiki) sendiri; syak: sebenarnya semuanya itu hanya berdasarkan pemikiran sempit, bukan kebenaran.

Indikator keberhasilan pendidikan ini diukur dengan munculnya sikap pada diri peserta didik seperti: 1) Tidak curiga pada orang lain;2) Tidak meremehkan orang lain; 3) 
Bersikap dan berperilaku yang menunjukkan sikap percaya terhadap orang lain; 4) Bersikap dan berperilaku bahwa orang lain dapat melakukan sesuatu dengan baik.

\section{Saling Percaya (Bulan ke-11)}

Tujuan nilai ini adalah peserta didik mempunyai kesadaran untuk menjunjung tinggi komitmen yang telah dibuat bersama dan yakin bahwa orang lain bisa dipercaya. Menganggap atau yakin bahwa seseorang itu jujur (tidak jahat dsb.) dan punya kemampuan/ kelebihan untuk mencapai harapan bersama.

Indikator keberhasilan pendidikan ini diukur dengan munculnya sikap pada diri peserta didik seperti: 1) Tidak saling mencurigai; 2) Melaksanakan tanggung jawab bersama; 3) Memberikan kepercayaan kepada wakil-wakil yang dipercayai untuk melaksanakan permusyawaratan.

\section{Tanggung Jawab (Bulan ke-12)}

Tujuan nilai ini adalah peserta didik mempunyai kesadaran untuk mau melakukan sesuatu yang menjadi kewajibannya, kesadaran dalam melakukan hak dan kewajibannya secara seimbang dapat tidak mengganggu kepentingan umum, tindakannya dapat dipertanggungjawabkan secara moral dan sosial, berani menanggung segala sesuatu sebagai dampak dari tindakannya (kalau terjadi apa-apa boleh dituntut, dipersalahkan, diperkarakan dan sebagainya).

Indikator keberhasilan pendidikan ini diukur dengan munculnya sikap pada diri peserta didik seperti: 1) Mengerjakan tugas dengan selesai; 2) Mengerjakan tugas tepat waktu; 3) Mau menerima resiko atas perbuatannya; 4) Mengerjakan sesuatu yang tidak merugikan dirinya dan orang lain; 5) Berani membela kebenaran dan keadilan.

\section{Analisis}

Dari bangunan konsep pendidikan multikultural di atas, Madrasah Pembangunan awalnya mencoba menerapkan kegiatan penguatan pendidikan multikultural itu dengan cara diterjemahkan dalam berbagai mata pelajaran dan dengan cara eksklusif sebagai upaya implementasi konsep pendidikan multikultural yang digagasnya. Namun patut dipahami bahwa mata pelajaran di madrasah yang berkaitan secara khusus dengan pembentukan etika atau prilaku sangat banyak, selain Pendidikan Kewarganegaraan (PKN) Madrasah mengajarkan etika melalui pelajaran Aqidah akhlak, Al Qur'an Hadits dan Sejarah Islam. Ada kesan di madrasah sering terjadi perulangan tema dalam beberapa mata pelajaran, walaupun dari sisi lain bisa dilihat saling menguatkan.

Sekilas perumusan pendidikan multikultural di madrasah, mengingat banyaknya mata pelajaran yang terkait dengan pembentukan etika, terasa absurd atau seperti "menggarami lautan." Laut yang pada dasarnya sudah asin, sudah pasti tidak perlu lagi diberi garam untuk meningkatkan kualitasnya. Namun menurut pengkaji, Perumusan konsep pendidikan multikultural di madrasah dengan adanya berbagai mata pelajaran terkait dengan pembentukan etika bukan berarti tidak begitu bermanfaat di madrasah. Wacana pendidikan multikultural berfungsi mengingatkan kembali pokok-pokok nilai yang harus ditekankan dalam pembentukan karakter siswa.

Pendidikandimadrasahdalampengamatan pengkaji sejauh ini memberikan pemahaman moderatisme yang cukup fokus. Peserta didik madrasah dalam banyak hak menunjukkan sikap toleransi yang sangat tinggi terhadap berbagai perbedaan yang ada di masyarakat. Realitas siswa madrasah yang dari sisi agama relatif homogen, menguatkan toleransi siswa terhadap bentuk-bentuk perbedaan terjadi dalam hal-hal yang terjadi di internal umat Islam. Banyak madrasah yang mengajarkan berbagai hal yang dulu sering dianggap sebagai 
pemicu konflik internal agama seperti sholat subuh pakai qunut atau tidak, bacaan iftitah setelah takbiratul ihram menggunakan bacaan "kabiiron" atau "Ba'id Baini", sholat tarawih 23 raka'at atau 11 rakaat di ajarkan di masingmasing madrasah sesuai dengan pemahaman keagamaan lokal yang dimiliki umat setempat. Madrasah tidak mengharuskan salah satunya sebagai pilihan satu-satunya madrasah. Ini berbeda dengan sekolah atau lembaga pendidikan yang nyata-nyata dimiliki ormas keagamaan Muhammadiyah atau nahdlatul Ulama yang sering menjadikan lembaga pendidikan sebagai media ideologisasi mereka.

Dengan penajamannilai-nilaimultikultural yang dirumuskan dalam 12 nilai utama yang diimplementasikan dalam 12 bulan pelajaran menjadi pengingat kembali atau mempertajam penanaman nilai-nilai yang akan diwujudkan dalam lingkungan pendidikan. Dahulu, konsep pengembangan nilai di lingkungan madrasah banyak bentumpu pada konsep 4 sifat utama rasulullah, yaitu siddiq (benar), amanah (dapat dipercaya), tabligh (menyampaikan) dan fathonah (cerdas). Empat sifat itu telah menjadi paradigma dasar pembentukan sikap siswa di lingkungan madrasah. Dengan adanya nilai-nilai yang perlu ditambahkan dalam rangka mengembangkan sikap multikultural, menurut pengkaji, telah memberi warna baru pembentukan mental siswa.

Pendidikan mental di lingkungan madrasah di beberapa segi bisa dikatakan berhasil, kalau ukurannnya dilihat dari anak-anak madrasah relatif berperilaku sopan, jarang terjadi perkelahian massal antara siswa-siswa madrasah, mempunyai pemahaman dasardasar agama yang cukup. Namun bila dilihat dari konteks pendidikan global yang meminta syarat kualitas, dan daya saing, nampaknya madrasah perluintropeksidiri. Dunia madrasah di indonesia terkesan prestasinya datar-datar aja (flat), kurang kompetitif dan masih agak gagap untuk menatap persaingan global. Wilayah ini menurut pengkaji hukumnya wajib dieksplorasi lebih lanjut oleh dunia madrasah.
Kualitas, mutu dan daya saing adalah konsep kunci lembaga pendidikan masa depan.

Dalam rangka pembentukan karakter siswa madrasah, selain sifat-sifat utama yang menjadi nilai utama pendidikan multikultural, madrasah jangan lupa merumuskan secara kuat konsep-konsep etika yang dibutuhkan dalam rangka penguatan jati diri dan kesiapan dalam menghadapi persaingan skills dalam mengahadpi pasar dan globalisme. Nilai-nilai seperti percaya diri, bekerja yang berkualitas dan sikap kompetitif perlu disemaikan menjadi sikap utama para siswa di lingkungan madrasah.

Pilihan ini bukan diambil didasarkan pada penilaian bahwa sifat-sifat rasul belum cukup untuk menghadapi konteks dunia saat ini, tetapi lebih dimaksudkan untuk mengeksplorasi keempat sifat utama rasul itu dalam konteks-konteks kekinian dengan memperkaya makna-makna baru untuk mendukung terimplementasikannya sikapsikap kenabian yang tercermin dari sifat-sifat utama rasul.

\section{PENUTUP}

\section{Kesimpulan}

Dari kajian tentang pendidikan multikultural di madrasah dengan mengambil kasus percobaaan pendidikan multikultural di Madrasah pembangunan Ciputat Tangerang, ada beberapa poin yang dapat ditarik kesimpulan: 1) pendidikan multikultural di lingkungan madrasah sebenarnya bukan masalah baru karena di lingkungan madrasah nilai-nilai multikultural itu telah diajarkan dalam banyak mata pelajaran seperti al qur'an Hadits, aqidah Akhlak, sejarah Islam di luar mata pelajaran Pendidikan KewargaNegaraan (PKN) yang diamanatkan oleh Undang-Undang Sistem Pendidikan Nasional; 2) namun begitu, pewacanaan pendidikan multikultural di madrasah bukan berarti tidak penting, karena dengan nilai-nilai 
tertentu yang dicoba dirumuskan kembali oleh pengelola Madrasah pembangunan telah membangunkan kesadaran baru tentang nilai-nilai tertentu yang dibutuhkan dalam menghadapi masyarakat multikultural seperti toleransi, empati, kerjasama; 3) Pendidikan etika yang menjadi prinsip utama dalam pendidikan multikultural, selama ini di lingkungan madrasah lebih banyak mengarusutamakan (mainstreaming) empat sifat utama rasululllah (Siddiq, Amanah, tabligh, fathonah) dan menjauhkan dari sifat sebaliknya (Kidzib, Khianat, Kitman, baladah) ke depan perlu diperkaya lagi dengan penambahan nilai-nilai etika yang dibutuhkan dan sesuai dengan konteks zamannya seperti nilai-nilai percaya diri, bekerja berkualitas dan berdaya saing.

\section{Rekomendasi}

Kajian ini merekomendasikan perlunya dunia madrasah di Indonesia untuk memulai merumuskan nilai-nilai utama yang perlu dan akan dikembangkan lembaga pendidikan madrasah di tanah air agar lembaga pendidikan madrasah dapat menjadi lembaga pendidikan terdepan dalam membangun karakter anak didiknya, serta secara lebih luas terdepan dalam membangun karakter bangsanya.

\section{SUMBER BACAAN}

Burbules dan Torres (2000): Globalization and Education: Critical Perspective. New York, Routledge.

Freire, Paulo (1984): Pendidikan Sebagai Praktek Pembebasan, terj. Alois A. Nugroho. Jakarta: Gramedia.

Lauder, Hugh et al. (2006): Education, Globalization \& Social Change. Oxford: Oxford university Press

Lawton, Denis dan Robert Cowen (2001): "Values, Culture and Education: an Overview" dalam buku Values, Culture and Education, USA: Stylus Publishing Inc.

Menon, M. Govin Kumar (2007): "Globalization and Education: An Overview" in Sorondo (ed.) Globalization and Education. Berlin: de Gruyter.

Tilaar, H.A.R. (2002): Perubahan Sosial dan Pendidikan: Pengantar Pedagogik Transformatif untuk Indonesia. Jakarta: Grasindo.

Safa, Helen Ickhen. (1971): "Education, Modernization, and the The Proses of National Integration, " dalam Anthropological Perspectives on Education (edit by Murray Wax et al.). New York: Basic Books, Inc,

Yakin, Ainul (2005): Pendidikan Multikultural: CrossCultural Understanding untuk Demokrasi dan Keadilan, Yogyakarta: Pilar Media.

Yon Sugiono, "Nilai-nilai Pendidikan Multikultural" (makalah yang dipresentasikan dalam Seminar yang diadakan oleh Universitas Atmadjaya, Jakarta)

Kurikulum MI Pembangunan UIN Jakarta, 2007 